Vol. 9 (3): 537-542 (2019)

\title{
PREVALENCE OF EHRLICHIA SPP IN TICKS COLLECTED FROM DOGS IN PROVINCE OF VAN IN TURKEY
}

\author{
Adnan Ayan ${ }^{1 *}$, Ozlem Orunc Kilinc ${ }^{2}$, Ali Bilgin Yilmaz ${ }^{3}$, Ali Rıza Babaoglu ${ }^{4}$ \\ I*Department of Genetics, Faculty of Veterinary Medicine, Van Yuzuncu Yil University, Tusba, Van, Turkey; \\ ${ }^{2}$ Özalp Vocational School, Van Yuzuncu Yil University, Van, Turkey; \\ ${ }^{3}$ School of Health, Van Yuzuncu Yil University, Van, Turkey; \\ ${ }^{4}$ Department of Virology, Faculty of Veterinary Medicine, Van Yuzuncu Yil University, Van, Turkey; \\ "Corresponding Author Adnan AYAN, e-mail: adnanayan@yyu.edu.tr;
}

Received June 2019; Accepted July 2019; Published August 2019;

DOI: https://doi.org/10.31407/ijees9317

\begin{abstract}
Ticks Rhipicephalus sanguineus of Rhipicephalus strain of Ixodidae family are biological mediators to transfer of Rickettsia pathogens such as Ehrlichia and Anaplasma in animals. In the present study, a total of 220 ticks were collected from 55 infested dogs. The ticks' taxonomy was carried out through microscopically. Additionally, DNA extraction from ticks was conducted and nested PCR was performed to differentiate the Ehrlischia spp. The obtained results indicates that collected ticks were belong to Rhipicephalus sanguineus of Rhipicephalus strain of Ixodidae family of ticks. The PCR results showed Ehrlichia spp. was present in ticks and E. canis was more common (50 of 220 ticks) than E. ewingii ( 3 of 220 ticks). In conclusion, E. canis was firstly detected in $R$. sanguineus tick in dogs in the Province of Van in Turkey. E. ewingii was firstly detected in $R$. sanguineus tick in dogs in Turkey. Its presence in dogs indicates the potential factor for public health hazard in Turkey
\end{abstract}

Keywords: Dog, Ehrlichia spp, Nested PCR, Rhipicephalus sanguineus. 